\title{
Research on Financial Performance of Chinese Airline Companies
}

\author{
-Based on Factor Analysis
}

\author{
Wang Jia-kang* \\ School of Economic and Management \\ Civil Aviation Management Institute of China \\ Beijing, 100102, China \\ wjksunny@126.com
}

\begin{abstract}
In China's social, economic activities and the dual drive of reform and opening up, China's middle class has been expanding rapidly. The air travel demand of Chinese middle class has driven the development of China's aviation industry rapidly. And China has become a world aviation giant next only to the United States. The article analyzes financial performance of Chinese airline companies with the methods of factor analysis. The methods gives preparative study and synthetic analysis through macro and micro views. Studies have shown that the development of Chinese airlines is imbalance on the whole. In particular, transport aviation companies developed better than the general aviation companies. But every aviation company has some unique problems. There is further room for improvement. The conclusions reached in this article not only pointed out the direction of China's airline companies for the future development but also provided references of aviation development for our government.
\end{abstract}

Keywords-Airline companies; Financial strategy; Factor analysis; Performance evaluation

\section{INTRODUCTION}

In 2015 , the turnover of airline industry completed 728.25 billion passengers, up $15 \%$ over the previous year; the air cargoes and emails completed 20.8 billion ton- miles, up $10.8 \%$ over the previous year.

Comprehensive evaluation is very important for Chinese airline companies. The methods reflected in the two aspects, one is that the airline can find out whether it was progress compared with its previous data; the other is that airlines companies can view their ranking in the whole aviation industry. And then found that the company has some shortcomings and deficiencies. So the company can correct it in subsequent work.

Because of the property of the company's financial strategy, it is difficult to evaluate it. And there are too many indicators and strong subjectivity. The evaluation of enterprise financial strategy itself is not very objective. If we use this method for a long time, it will mislead the investors, creditors and the public.
Based on this, this paper uses factor analysis to evaluate the overall financial situation of China's airline companies. The samples is listed in Shanghai and Shenzhen stock markets. Factor analysis has a strong objectivity, that is, the method uses a number of indicators to model a few of integrated indicators, thus reducing the dimensionality of the dimension.

\section{REVIEW OF THE LITERATURE}

The literature about the company's financial strategy performance evaluation can be broadly divided into two categories. One is to study the impact of other factors on the performance of financial strategy. It commonly used regression method or panel data methods. Such as, Reference [1] study relationship of collaborative, agile supply chain and business performance. Reference [2] study the relationship between entrepreneur social capital and firm performance. Reference [3] study the relationship between the knowledge capital and business performance. Reference [4] studies the corporate governance on the Relation between R\&D Input and Firm Performance. Reference [5] studies relationship of the fairness preference, the Incentives of the executive team championship and firm performance.

However, the study that based on the above method of multiple regression analysis or panel model analysis is just to test whether single influencing factors such as knowledge capital or simply a few more influencing factors such as the fairness preference, the Incentives of the executive team championship on firm performance will affect the firm performance. It has no specific quantitative analyses and contrast analyses. It also ignored the integrated or comprehensive factors to the evaluation of the performance. And the study above does not completely rule out the impact of collinearity and heteroscedasticity which have a certain influence on the statistical results.

The other is integrated comprehensive evaluation of the performance of company strategic. Main methods are factor analysis and cluster analysis literature. Reference [6] applied cluster analysis to study the special treated (ST) companies in China. Reference [7]-[9] applied cluster analysis to study the operations of Chinese trust and investment corporation. Reference [10] applied cluster analysis to study Chinese listed 
companies' financial performance. Reference [11] applied cluster analysis to study Chinese electric power Listed companies performance.

However, cluster analysis can only classify the similar level of economic development of companies as a class. It cannot achieve the purpose of the quantitative evaluation of the level of development for the companies. Therefore, the evaluation of the performance of corporate financial strategic usually apply the method of factor analysis. For example, Reference [12] apply the method of factor analysis to evaluate technological innovation ability of Manufacturing Industry in Hubei, China. Reference [13] apply the method of factor analysis to evaluate the sustainable growth of Chinese private listed companies. Reference [14] apply the method of factor analysis to evaluate the financial performance of Chinese companies listed in the USA.

Based on the above analysis, this paper intends to use factor analysis method to evaluate the development level of China's airlines companies. We adopt the factor analysis method, which is based on the following advantages of the method.

- Comprehensive. The basic condition of the method is $\mathrm{n}>\mathrm{P}$., that is, the sample capacity is more than the number of variables. So we can choose more variables in order to reflect the overall operation of the enterprise;

- Comparability. The data have been standardized by the model of non-dimensional processing. The comparable index between the variables are reasonable.

- Objectivity. The weight of the comprehensive evaluation function is objective and reasonable. Because the paper calculate the weight according to the variance contribution rate of each factor.

\section{SAMPLE SELECTION AND CONSTRUCTING INDEXES SYSTEM}

In this paper, we use the factor analysis to evaluate Chinese airline companies' financial strategy performance. These companies were listed in the Shanghai stock exchange and Shenzhen stock exchange. The data of model comes from Shanghai stock exchange and Shenzhen stock exchange, during 2013-2015.

By study a great deal of literature, the paper selects 11 representative indicators. They are: current ratio, debt-to-equity, inventory turnover ratio, sales net profit margin, the growth rate of net assets, accounts receivable turnover ratio, net profit growth, net profit margin of assets, quick ratio, the ratio of main business income growth and asset-liability ratio. See in the table I.

\section{IV.PROCESS AND THE RESULTS OF FACTOR ANALYSIS}

\section{A. Standardization processing and correlation matrix}

In the above index system, there are two indicators are the appropriateness of the indicators, namely, the flow rate and the ratio of quick indicators. The other 9 are positive indicators. Therefore, before using the method of factor analysis, we should deal with these indexes [15].

At the same time, due to the different units of the indicators, in order to unify the comparison, we need to eliminate the unit between the different indicators, so the data of article has validity and comparability in the analysis and derivation. To this end, we conducted standardized processing of data, on this basis, the paper constructs correlation coefficient matrix with processing variables, the correlation coefficient matrix as shown in Table II, we can see from Table II, the correlation between different variables are strong.

TABLE I. INDEXES

\begin{tabular}{|l|l|l|}
\hline \multicolumn{1}{|c|}{ Name of index } & Code of index & \multicolumn{1}{c|}{ The formula } \\
\hline current ratio & $\mathrm{X} 1$ & Current assets / current liabilities \\
\hline quick ratio & $\mathrm{X} 2$ & Liquid assets / current liabilities \\
\hline inventory turnover ratio & $\mathrm{X} 3$ & Sales revenue / inventory \\
\hline accounts receivable turnover ratio & $\mathrm{X} 4$ & Sales revenue / receivables \\
\hline sales net profit margin & $\mathrm{X} 5$ & Net profit / sales revenue \\
\hline net profit growth & $\mathrm{X} 6$ & (Net profit this year - net profit last year) / previous year net profit \\
\hline net profit margin of assets & $\mathrm{X} 7$ & Net profit / total assets \\
\hline the growth rate of net assets & $\mathrm{X} 8$ & $\begin{array}{l}\text { (End of period net assets - beginning of period net assets) / } \\
\text { opening net assets }\end{array}$ \\
\hline $\begin{array}{l}\text { the ratio of main business income } \\
\text { growth }\end{array}$ & $\mathrm{X} 9$ & $\begin{array}{l}\text { Main business income for this year - Main business income } \\
\text { for last year) / Main business income for last year }\end{array}$ \\
\hline debt-to-equity ratio & $\mathrm{X} 10$ & Total liabilities / shareholders' equity \\
\hline asset-liability ratio & $\mathrm{X} 11$ & Total liabilities / total assets \\
\hline
\end{tabular}


TABLE II. CORRELATION MATRIX

\begin{tabular}{|l|l|l|l|l|l|l|l|l|l|l|l|l|}
\hline & $\mathrm{X} 1$ & $\mathrm{X} 2$ & $\mathrm{X} 3$ & $\mathrm{X} 4$ & $\mathrm{X} 5$ & $\mathrm{X} 5$ & $\mathrm{X} 6$ & $\mathrm{X} 7$ & $\mathrm{X} 8$ & $\mathrm{X} 9$ & $\mathrm{X} 10$ & $\mathrm{X} 11$ \\
\hline $\mathrm{X} 1$ & 1.000 & .976 & -.040 & -.314 & .634 & -.716 & .048 & -.684 & -.428 & -.836 & -.940 & 1.000 \\
\hline $\mathrm{X} 2$ & .976 & 1.000 & .122 & -.132 & .733 & -.716 & .156 & -.762 & -.371 & -.868 & -.917 & .976 \\
\hline $\mathrm{X} 3$ & -.040 & .122 & 1.000 & .338 & .088 & -.146 & -.055 & -.216 & -.118 & -.002 & .163 & -.040 \\
\hline $\mathrm{X} 4$ & -.314 & -.132 & .338 & 1.000 & .401 & .298 & .666 & -.088 & .455 & -.059 & .176 & -.314 \\
\hline $\mathrm{X} 5$ & .634 & .733 & .088 & .401 & 1.000 & -.208 & .783 & -.651 & .309 & -.773 & -.655 & .634 \\
\hline $\mathrm{X} 6$ & -.716 & -.716 & -.146 & .298 & -.208 & 1.000 & .378 & .790 & .759 & .423 & .574 & -.716 \\
\hline $\mathrm{X} 7$ & .048 & .156 & -.055 & .666 & .783 & .378 & 1.000 & -.211 & .794 & -.353 & -.148 & .048 \\
\hline $\mathrm{X} 8$ & -.684 & -.762 & -.216 & -.088 & -.651 & .790 & -.211 & 1.000 & .217 & .482 & .520 & -.684 \\
\hline $\mathrm{X} 9$ & -.428 & -.371 & -.118 & .455 & .309 & .759 & .794 & .217 & 1.000 & .201 & .385 & -.428 \\
\hline $\mathrm{X} 10$ & -.836 & -.868 & -.002 & -.059 & -.773 & .423 & -.353 & .482 & .201 & 1.000 & .941 & -.836 \\
\hline $\mathrm{X} 11$ & -.940 & -.917 & .163 & .176 & -.655 & .574 & -.148 & .520 & .385 & .941 & 1.000 & -.940 \\
\hline
\end{tabular}

\section{B. The applicability on the factor analysis}

As mentioned above, there is a certain correlation between indicators. And that is the premise of factor analysis. In the test of the applicability of factor analysis, Bartley ball test was adopted. The Bartlett sphere test takes the correlation coefficient matrix of variables as a starting point, and is used to test whether the correlation matrix is a unit matrix. The test statistic obeys the chi square distribution, and the zero hypothesis is that the correlation coefficient matrix is a unit matrix, and the normal hypothesis test can be used to judge whether the non-diagonal elements of the correlation coefficient matrix are significantly different from zero. Using the Bartlett sphere test for significant test, chi square statistic value of 28.75 , and significant probability is 0.017 , less than $5 \%$, therefore we rejected the null hypothesis testing and accepted the opposite assumption. The data has significant correlation, and it is suitable for factor analysis.

\section{Eigenvalue, eigenvalue contribution rate and cumulative eigenvalue contribution rate}

The principal component analysis was used to extract the eigenvalues and eigenvalues, contribution rates and cumulative contribution rates of the rotated correlation matrix also were calculated. As can be seen from table III, there are 3 principal components eigenvalue greater than
1, the first principal component explained $49.71 \%$ of the variance for all variables, the second principal components explained $27.496 \%$ of the variance of all variables, the third principal components explained $12.716 \%$ of the variance of all variables. The cumulative contribution rate of sample variance was $89.922 \%$ of the variance of all variables.

Therefore, we can believe that the first 3 principal components combine the vast majority of the original indicators, and the extraction of the 3 principal components can better explain the financial performance of Chinese airline companies.

\section{Factor to obtain and its rotation}

Table IV is the initial factor according to the data we obtained by SPSS17.0. The factor analysis model not only for the purpose to find the common factor, it is more important to know the meaning of each common factor. The actual problems are analyzed in order to solve them. However, the initial factors we get from the ways of principal variables is not typical outstanding. And it is difficult to distinguish the exact meaning between different factors. It is not suitable for practical problems. So it is necessary to carry on the factor rotation, table V. shows the results of the following factor rotation.

TABLE III. TOTAL VARIANCE EXPLAINED

\begin{tabular}{|l|l|l|l|l|l|l|}
\hline component & \multicolumn{2}{|l|}{ Initial eigenvalues } & \multicolumn{2}{l|}{ Extraction suns of squared loadings } \\
\hline & \multicolumn{1}{|c|}{$\begin{array}{c}\text { \% of } \\
\text { total }\end{array}$} & $\begin{array}{c}\text { vance } \\
\text { variance }\end{array}$ & Cumulative \% \\
\hline 1 & 5.468 & 49.710 & 49.710 & 5.468 & 49.710 & 49.710 \\
\hline 2 & 3.025 & 27.496 & 77.206 & 3.025 & 27.496 & 77.206 \\
\hline 3 & 1.399 & 12.716 & 89.922 & 1.399 & 12.716 & 89.922 \\
\hline 4 & .640 & 5.820 & 95.742 & & & \\
\hline 5 & .426 & 3.872 & 99.613 & & & \\
\hline 6 & .043 & .387 & 100.000 & & & \\
\hline 7 & $5.394 \mathrm{E}-16$ & $4.904 \mathrm{E}-15$ & 100.000 & & & \\
\hline 8 & $3.149 \mathrm{E}-16$ & $2.863 \mathrm{E}-15$ & 100.000 & & & \\
\hline 9 & $1.943 \mathrm{E}-17$ & $1.767 \mathrm{E}-16$ & 100.000 & & & \\
\hline 10 & $-3.828 \mathrm{E}-17$ & $-3.480 \mathrm{E}-16$ & 100.000 & & & \\
\hline 11 & $-3.478 \mathrm{E}-16$ & $-3.162 \mathrm{E}-15$ & 100.000 & & & \\
\hline
\end{tabular}


TABLE IV. COMPONENT MATRIX

\begin{tabular}{|l|l|l|l|}
\hline & \multicolumn{3}{|c|}{ component } \\
\hline & 1 & 2 & 3 \\
\hline current ratio & -.967 & -.124 & -.155 \\
\hline quick ratio & -.991 & .003 & .015 \\
\hline inventory turnover ratio & -.063 & .057 & .891 \\
\hline accounts receivable turnover ratio & .103 & .759 & .451 \\
\hline sales net profit margin & -.731 & .677 & -.003 \\
\hline net profit growth & .752 & .504 & -.290 \\
\hline net profit margin of assets & -.161 & .977 & -.105 \\
\hline the growth rate of net assets & .787 & -.081 & -.361 \\
\hline $\begin{array}{l}\text { the ratio of main business income } \\
\text { growth }\end{array}$ & .393 & .840 & -.184 \\
\hline debt-to-equity ratio & & & \\
\hline asset-liability ratio & .881 & -.225 & .178 \\
\hline
\end{tabular}

TABLE V. ROTATED COMPONENT MATRIX

\begin{tabular}{|l|r|r|r|}
\hline \multirow{2}{*}{} & \multicolumn{3}{|c|}{ component } \\
\cline { 2 - 4 } & \multicolumn{1}{|c|}{1} & \multicolumn{1}{c|}{2} & \multicolumn{1}{c|}{3} \\
\hline current ratio & -.963 & -.203 & -.074 \\
\hline quick ratio & -.981 & -.092 & .108 \\
\hline inventory turnover ratio & .023 & -.016 & .895 \\
\hline accounts receivable turnover ratio & .081 & .729 & .501 \\
\hline sales net profit margin & -.783 & .603 & .122 \\
\hline net profit growth & .672 & .593 & -.315 \\
\hline net profit margin of assets & -.255 & .963 & -.007 \\
\hline the growth rate of net assets & .750 & .021 & -.438 \\
\hline the ratio of main business income & .299 & .885 & -.149 \\
growth & & & \\
\hline debt-to-equity ratio & .910 & -.153 & .075 \\
\hline asset-liability ratio & .949 & .079 & .206 \\
\cline { 2 - 4 }
\end{tabular}

We can get equations below.

$$
\begin{aligned}
& F_{1}=-0.963 X_{1}-0.981 X_{2}+0.023 X_{3}+0.081 X_{4} \\
& -0.783 X_{5}+0.672 X_{6}-0.255 X_{7}+0.75 X_{8} \\
& +0.299 X_{9}+0.91 X_{10}+0.949 X_{11}
\end{aligned}
$$

$F_{2}=-0.203 X_{1}-0.092 X_{2}-0.016 X_{3}+0.729 X_{4}$

$+0.603 X_{5}+0.593 X_{6}+0.963 X_{7}+0.021 X_{8}$

$+0.885 X_{9}-0.153 X_{10}+0.079 X_{11}$

$F_{3}=-0.074 X_{1}+0.108 X_{2}+0.895 X_{3}+0.501 X_{4}$

$+0.122 X_{5}-0.315 X_{6}-0.007 X_{7}-0.438 X_{8}$

$-0.149 X_{9}+0.075 X_{10}+0.206 X_{11}$

By rotating public factors the model can explain the original data. But the explanation did not increase. And the rotated factor loading matrix and factor score coefficient matrix is changed. The factor loading matrix elements in the root tends to 0 or +1 , thus we can obtain the common factor with clear economic significance. The larger the load factor in the load matrix, the better the ability of comprehensive index interpretation corresponding to the original index.

In the first principal component factor, asset-liability ratio, asset-liability ratio are significant bigger than other indexes, the first principal component can be called the solvency factor. In the second principal component factor, the net profit margin of assets, the ratio of main business income growth are significant bigger than other indexes, the second principal component can be called the earnings growth capacity factor. In the third principal component factor, inventory turnover ratio, accounts receivable turnover ratio are significant bigger than other indexes, the third principal component can be called the operating capacity factor.

\section{E. Factor score and its ranking}

SPSS 17 can calculate the score of 3 factors, and the 3 factor scores as new variables are saved in the SPSS data editing window. The score of each factor is shown in table, and the individual factors in parentheses are ranked. In order to make a comprehensive evaluation of the financial performance of Chinese airline companies, it is necessary to use the factor scores in the table VI to build a comprehensive evaluation function with the respective variance contribution rate as the weight: The equation is below.

$$
F=\left(49.71 \% F_{1}+27.496 \% F_{2}+12.716 \% F_{3}\right) / 89.922 \%
$$

\begin{tabular}{|c|c|c|c|c|c|c|}
\hline \multirow{2}{*}{ Company } & \multirow{2}{*}{ Code } & \multicolumn{3}{|c|}{ Factor score and its ranking } & \multicolumn{2}{|c|}{ Comprehensive ranking } \\
\hline & & $F_{1}$ & $F_{2}$ & $F_{3}$ & $F$ & rank \\
\hline $\begin{array}{l}\text { China Southern Airlines Company } \\
\text { Limited }\end{array}$ & 603885 & $.4159(4)$ & $1.465(1)$ & $-.417(4)$ & .556 & 1 \\
\hline $\begin{array}{l}\text { China Eastern Airlines Corporation } \\
\text { Limited }\end{array}$ & 600029 & $1.043(1)$ & $-.322(4)$ & $-.679(6)$ & .344 & 2 \\
\hline Air China Limited & 600115 & $.795(2)$ & $-.717(6)$ & $.117(3)$ & .213 & 3 \\
\hline JUNEYAO AIRLINES Co., Ltd & 601111 & $.440(3)$ & $-.284(3)$ & $-.611(5)$ & .063 & 4 \\
\hline Hainan Airlines Co., Ltd. & 601021 & $-.828(6)$ & $1.398(2)$ & $.594(2)$ & .048 & 5 \\
\hline Spring Airlines Co., Ltd. & 600221 & $-.071(5)$ & $-.688(5)$ & $1.935(1)$ & .022 & 6 \\
\hline $\begin{array}{l}\text { CITIC OFFSHORE HELICOPTER } \\
\text { CO.,LTD. }\end{array}$ & 000099 & $-1.795(7)$ & $-.853(7)$ & $-.940(7)$ & -1.246 & 7 \\
\hline
\end{tabular}

TABLE VI. FACTOR SCORE AND ITS RANKING

In factor analysis, the data were standardized. The scores of common factor scores and synthetic scores were zero. Its positive and negative sizes have no real meaning. If the score is greater than zero, the company performance is better. If the score is less than zero, the performance is poor, and the 
absolute value of the number is bigger, the performance of Chinese airline companies is poorer.

\section{CONCLUSION}

We can see from table 6 that the high rank airline companies are most transport aviation companies, and the low rank companies are most the general aviation companies.

In terms of operating capacity, the top two companies are Spring Airlines Co., Ltd and Hainan Airlines Co., Ltd. In terms of solvency, the top two companies are China Eastern Airlines Corporation Limited and Air China Limited. The worst performance company is CITIC OFFSHORE HELICOPTER CO., LTD. The weight of solvency is in the second place. In terms of earnings growth ability, the top two companies are China Southern Airlines Company Limited and Hainan Airlines Co., Ltd.

From comprehensive analysis of the various factors, the composite scores of the top two are China Southern Airlines Company Limited and China Eastern Airlines Corporation Limited. But they have not excellent performance in all three factors.

Based on the above analysis, we propose the following three policy recommendations.

Firstly, airline companies should strengthen the connection between the main airlines and regional airlines of air transport network. Chinese airline companies are lack of effective coordination between the main and regional transport, especially in the same region. It affected the effective convergence of regional flights and main flights, and reduced the operating income, therefore, airline companies should strengthen the air transport network connection between the main airlines and regional airlines

Secondly, airline companies should constantly innovate business model. With the competition of civil aviation industry, it emerges business models in aviation industry likes an endless stream. It includes full service airlines, commercial airlines, low-cost airlines, local airlines, and even integrated service mode, each business model continues to permeate each other. Although each model has its own rules of survival, each airline should innovate to find business model that suitable for their own.

Lastly, airline companies should use a variety of measures to reduce costs. It should effectively integrate of airline resources by lean management, quantifying the cost of each process, innovating management tools, and increasing technology research and development. Thereby airline companies can effectively reduce the unit cost of operating.

\section{REFERENCES}

[1] C.L. Liao, M.Q. Qiu and Y. Long, "An empirical study on the relationship among collaborative relationship, agile supply chain and business performance", Systems Engineering - Theory \& Practice , vol.28, no.6, pp.115-128, 2008

[2] J.H. Sun and C.M. Chen, "Research on the Relationship between Entrepreneur Social Capital and Firm Performance: An Empirical Analysis Based on Chinese Listed Companies in the Manufacturing Industry", Nankai Business Review, vol.12, no.2, pp.28-36,2009

[3] Y. Cao, X.H. Chen and Y.R. Ma, "Relationship between knowledge capital and enterprise performance based on enterprise life cycle", Systems Engineering--Theory \& Practice, vol.30, no.4, pp.577-586, 2010

[4] H.Y. Ben, "Moderating Effects of Corporate Governance on the Relation between R\&D Input and Firm Performance", Journal of Management Science, vol.5, pp.37-47, 2012

[5] B.G. Hang, "The Fairness Preference, the Incentives of the Executive Team Championship and Firm Performance", Journal of Business Economics, vol.11, pp.62-70, 2012

[6] Y.H. Zhao, "The use of cluster analysis as the method to study ST corporate" ,China Computerized Accounting, vol.9, pp.8-11, 2003

[7] Q.D. Li, "Evaluation and cluster analysis of listed companies' financial performance", Industrial Technology \& Economy, vol.24, no.8, pp.146-148, 2005

[8] K.L. Wang and J.W. Yao, L.R. Zou, "The cluster analysis of Trust and Investment Corporation in the 2005 operating”, Inquiry Into Economic Issues, vol.12:pp.184-187, 2007

[9] J. Miao, J.H. Yin, "The Application of Clustering Analysis to the Performance Appraisal of Listed Stock Companies", Journal Of Changji University, vol.4, 2009

[10] C.R. Guo and L. Liu, "Cluster analysis on the financial condition of listed bank companies", Management World, vol.1, pp.176-177, 2012

[11] Y.X. Qiu and S.H. Cheng, "factor analysis of Electric Power Listed Companies Performance", vol.15, pp.18-22, 2015

[12] M.L. Zhang and Z.J. Zhang, "Research on Technological Innovation Ability Evaluation of Manufacturing Industry in Hubei Based on the Factor Analysis", Science \& Technology Progress And Policy, vol.28, no.18, pp.123-125, 2011

[13] Y.X. Wang, L. YE and Y.M. Guan, "The Sustainable Growth of Private Listed Companies: Based on Factor Analysis", The Theory and Practice of Finance and Economics, vol.33, no.6, pp.61-65, 2012

[14] J.K. Wang and X.M. Guo, "Research on Financial Strategic Performance of Chinese Energy Enterprises Listed in USA: Based on Factor Analysis", In 2013 International Conference on Management Science \& Engineering, ICMSE2013, 2013, pp.928-933

[15] X.L. Li. and Z.F. Zhou, "Study on the evaluation of regional technology innovation ability system and regional difference based on factor analysis model”, Scientific Management Research , vol.2, pp.5-10, 2006 